\title{
Not all shellfish "allergy" is allergy!
}

\author{
Chee K Woo and Sami L Bahna*
}

\begin{abstract}
The popularity of shellfish has been increasing worldwide, with a consequent increase in adverse reactions that can be allergic or toxic. The approximate prevalence of shellfish allergy is estimated at $0.5-2.5 \%$ of the general population, depending on degree of consumption by age and geographic regions. The manifestations of shellfish allergy vary widely, but it tends to be more severe than most other food allergens.

Tropomyosin is the major allergen and is responsible for cross-reactivity between members of the shellfish family, particularly among the crustacea. Newly described allergens and subtle differences in the structures of tropomyosin between different species of shellfish could account for the discrepancy between in vitro cross-antigenicity and clinical cross-allergenicity. The diagnosis requires a thorough medical history supported by skin testing or measurement of specific lgE level, and confirmed by appropriate oral challenge testing unless the reaction was life-threatening. Management of shellfish allergy is basically strict elimination, which in highly allergic subjects may include avoidance of touching or smelling and the availability of self-administered epinephrine. Specific immunotherapy is not currently available and requires the development of safe and effective protocols.
\end{abstract}

\section{Introduction}

Seafood consumption has increased in popularity and frequency worldwide. The largest consumer is China, followed by Japan and United States of America. In 2009, Americans ate an average of 15.8 pounds of fish and shellfish per capita, with shrimp being the top choice at 4.1 pounds [1]. The increased production and consumption of seafood has been accompanied by increasing reports of adverse reactions to seafood. Such reactions can be immune-mediated allergic reactions or non-immunologic, with both presenting with similar symptoms.

\section{Prevalence and epidemiology}

Shellfish is one of the leading causes of food allergy in adults and is a common cause of food-induced anaphylaxis. In an international survey using a questionnaire administered to 17,280 adults (aged 20-44 years) from 15 countries, symptoms related to seafood were reported to be caused by shrimp in $2.3 \%$, oyster in $2.3 \%$, and fish in $2.2 \%$ [2]. In the United States, a telephone survey of 14,948 individuals revealed that $2-3 \%$ believed to have seafood allergy: $2.2 \%$ to shellfish and $0.6 \%$ to fish [3]. Shellfish allergy was much lower in children than in adults $(0.5$ vs $2.5 \%)$. In a decreasing frequency, the

\footnotetext{
* Correspondence: sbahna@|suhsc.edu

Allergy and Immunology Section, Louisiana State University Health Sciences Center, Shreveport, Louisiana 71130, USA
}

causative types of shellfish were shrimp, crab, lobster, clam, oyster and mussel.

The prevalence of shellfish allergy in Asian countries is higher than in western countries [4], and this might reflect the geographic consumption of shellfish. In a study of children residing in Singapore [5], the prevalence of shellfish allergy was more common in native children (4-6 years, 1.19\%; 14-16 years, 5.23\%) compared to expatriate children (4-6 years, $0.55 \%$; $14-16$ years, $0.96 \%)$. Specific shellfish allergy can reflect regional consumption of that particular species.

Only a few studies evaluated the natural history of shellfish allergy, and they seem to indicate that it is longlasting [6]. In a study of 11 subjects with shrimp hypersensitivity [7], shrimp-specific IgE levels in all subjects were relatively constant during the 24 months of the study and were not affected by shrimp challenge. Another study [8] however, revealed that children with shrimp allergy have higher specific IgE antibody levels, show more intense binding to shrimp peptides, and a greater epitope diversity than in adults, suggesting that sensitization to shrimp might decrease by age.

\section{Classification of shellfish (Figure 1)}

"Shellfish" and "seafood" are often used by the public interchangeably and with different meanings. "Seafood" is a general term that refers to any edible aquatic animals, 


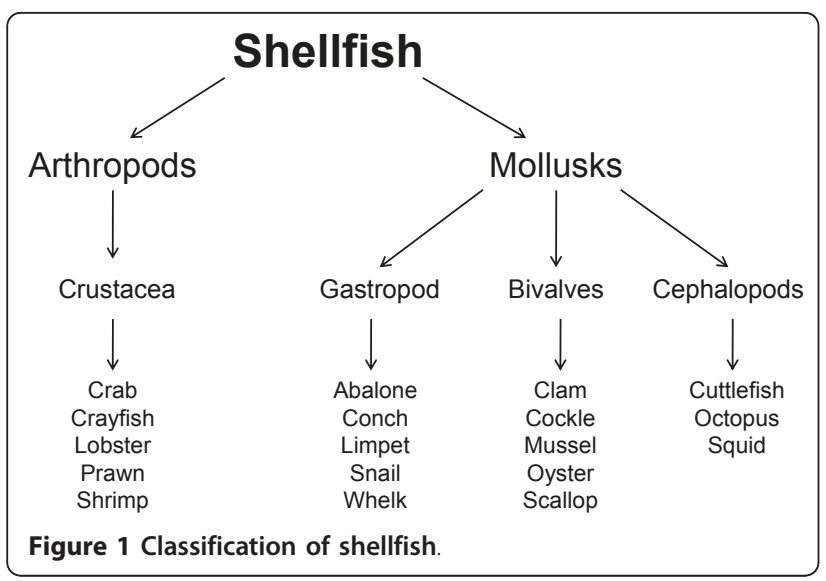

whereas "shellfish" refers to those with a shell or shelllike exoskeleton i.e. crustacea and mollusks. Crustacea are classified among arthropods together with arachnids and insects, whereas mollusks include Bivalves, Gastropods and Cephalopods.

\section{Shellfish toxic syndromes (Table 1)}

Shellfish poisoning frequently masquerade as an allergic reaction. Ingestion of contaminated shellfish results in a wide variety of symptoms depending on the concentration of toxins and amount consumed. Five types of shellfish poisoning have been identified [9]. Scombroid poisoning [10] has been linked to fish by the action of bacteria on muscle histidine and production of histamine. To the best of our knowledge, we did not encounter any reports in the English literature on scombroid poisoning from shellfish consumption.

\section{Paralytic shellfish poisoning}

Paralytic shellfish poisoning [11] is the best known and it is caused by saxitoxins. It is the most severe, with neurological symptoms predominating. Within $30 \mathrm{~min}-$ utes of ingestion, the first and most consistent presentation is numbness, tingling or burning of lips, tongue and throat. Paresthesias involve the face and neck and often spread to other parts of the body. Muscular weakness

\section{Table 1 Shellfish toxic syndromes}

- Paralytic shellfish poisoning
- Neurotoxic shellfish poisoning
- Diarrhetic shellfish poisoning
- Amnesic shellfish poisoning
- Azaspiracids shellfish poisoning
- Adverse reactions to bacterial or viral contamination
- Vibrio vulnificus
- Clostridium botulinum
- Staphylococcal enterotoxin
- Norwalk virus

then affects the extremities, and in more severe cases, dysphonia, dysphagia and ataxia occur. Paralysis may occur within 2-12 hours and may persist for as long as 72 hours. Bivalve mollusks such as mussels, clams and oysters assimilate and temporarily store saxitoxins, a complex of neurotoxins produced by dinoflagellates. In the United States, paralytic shellfish poisoning is a problem primarily in the New England states on the East Coast and in Alaska, California and Washington on the West Coast. It has also been reported in Asia, Africa, Europe, Oceania and South America.

\section{Neurotoxic shellfish poisoning}

Neurotoxic shellfish poisoning [11] is characterized by both gastrointestinal and neurologic symptoms. It resembles a mild case of paralytic shellfish poisoning but without paralysis. The onset occurs within 3 hours of ingestion of shellfish contaminated with brevetoxins. Symptoms include numbness of lips, tongue and throat which then spread to other parts of the body. Muscular aches, dizziness, reversal of hot and cold temperature sensation occur along with nausea, vomiting, abdominal pain and diarrhea. Karenia brevis is the dinoflagellate that synthesizes brevetoxins, a group of related heatstable toxins that are responsible for the clinical manifestations of neurotoxic shellfish poisoning. In the United States, the illness is generally associated with the consumption of shellfish harvested along the coast of Gulf of Mexico from Florida to Texas and sporadically along the southern Atlantic coast. K. Brevis blooms are also known as "red tides" because of the red coloration of seawater. Unlike other shellfish toxins, the brevetoxins can aerosolize by surf and wave action along the beach during red tides. These irritant toxin aerosols can cause conjunctival irritation, sneezing and rhinorrhea that resemble an allergic response. Exposure to such toxins in individuals with underlying asthma or chronic obstructive pulmonary disease can lead to shortness of breath, non productive cough and wheezing.

\section{Amnesic shellfish poisoning}

Amnesic shellfish poisoning [9] presents initially with vomiting, diarrhea and abdominal cramping within 24 hours after ingestion of shellfish contaminated with domoic acid. In some cases, varying degrees of neurological dysfunction ensues within 48 hours, including confusion, loss of memory and disorientation. The loss of short term memory is unique to this type of shellfish poisoning. Other neurological symptoms are headache, hyporeflexia, hemiparesis, ophthalmoplegia and altered consciousness ranging from agitation to coma, seizures and myoclonus, especially affecting the face. The phytoplanktonic diatom Pseudo-nitzchia multiseries are the source of the toxic agent identified as domoic acid. This 
potent neurotoxin accumulates in mussels and clams that feed on toxic plankton during their bloom.

\section{Diarrhetic shellfish poisoning}

Diarrhetic shellfish poisoning [9] is the mildest and most benign of the toxic shellfish poisonings. Clinical features are limited to the GI tract and include diarrhea, nausea, vomiting, abdominal pain and cramps. Chills, fever or headache may be present in up to $10 \%$ of cases. These symptoms usually manifest in a period ranging from 30 mins to 6 hours after ingestion of contaminated shellfish. Patients often do not seek medical attention due to the transient nature of the illness and its spontaneous resolution. Diarrhetic shellfish poisoning is associated with the consumption of mussels, scallops, clams and oysters contaminated with biotoxins produced by toxic marine dinoflagellates during their blooms in summer.

\section{Azaspiracids shellfish poisoning}

Azaspiracids (AZA) [12] are polyether marine toxins that accumulate in various shellfish species and have been associated with severe gastrointestinal human intoxications. The first confirmed case was in 1995 in the Netherlands. This toxin has since been reported in Western Europe, Northwest Africa and Eastern Canada. There have been several attempts to identify the AZA producing organism(s) and the polyether structure of these compounds might suggest a dinoflagellate origin. Unlike many of the other well-described marine phycotoxins, relatively little is known about AZA. Similar to diarhetic shellfish toxins, human consumption of AZAcontaminated shellfish can result in severe acute symptoms that include nausea, vomiting, diarrhea, and stomach cramps that persist for 2-3 days. Toxicology studies have shown that AZA can induce widespread organ damage in mice and that they can be a potent toxin.

\section{Adverse reactions to shellfish from bacterial and viral etiologies}

In addition to the above specific five types of shellfish toxicity, the differential diagnosis should include bacterial toxins, viral and bacterial infections. Although rare, Vibrio vulnificus is the leading cause death related to seafood consumption in the United States. This bacterium is part of the natural flora of coastal environments worldwide and has been isolated in a variety of seafood including shrimp, fish, oysters and clams. Consumption of undercooked or raw seafood (primarily raw oysters) contaminated with $V$. vulnificus can result in severe fulminant sepsis and development of severe cellulitis with ecchymoses and bullae. Risk factors include immunocompromised conditions especially alcoholic liver disease, hepatitis B or hepatitis C, and male gender. Treatment includes antibiotics and supportive care.

Food-borne botulism occurs upon ingestion of food contaminated by preformed toxin that is produced by Clostridium botulinum. Initial manifestations are GI symptoms such as nausea, vomiting and diarrhea. Other initial symptoms include dry mouth, diplopia, blurred vision and photophobia caused by loss of pupillary light reflex. A symmetric descending flaccid paralysis may occur that can lead to respiratory failure.

Staphylococcal enterotoxin is produced by Staphylococcal aureus growing in the contaminated food. Onset of symptoms is usually rapid after ingestion. GI symptoms predominate with nausea, vomiting, abdominal cramps and diarrhea. This type of food poisoning usually occurs in foods that have been left at room temperature for some time.

Norwalk virus infection usually occurs after ingestion of contaminated raw shellfish and can spread through the fecal-oral route. Incubation period is 24-48 hours after exposure. Most common symptoms are nausea, vomiting and diarrhea which resolve after 24 hours.

\section{Shellfish toxicity recognition and management}

Shellfish poisoning may be under diagnosed particularly when mild, or misdiagnosed as allergy. The presence of similar symptoms in other individuals who shared the same meal, absence of prior reactions to the same shellfish and its subsequent tolerance without symptoms should favor toxicity. The level of suspicion should be higher in regions with seasonal algal blooms, high levels of biotoxins or toxic algae. In the majority of these toxic syndromes, the toxin does not alter the taste and appearance of the shellfish and is not inactivated by usual cooking.

Treatment for these toxic syndromes is mostly supportive with respiratory support in cases where neurological involvement can cause respiratory failure. In acute severe cases, gastric emptying and administration of activated charcoal has been recommended to help block further absorption of the toxins.

\section{Shellfish allergens (Table 2) [13]}

Hoffman et al [14] first isolated two allergens from raw and cooked shrimp, termed antigen I and antigen II respectively. The heat stable antigen II, demonstrated specific IgE binding in the sera of all 11 shrimp-allergic subjects tested. Subsequently, other studies confirmed that antigen II is the major shrimp allergen and was identified as tropomyosin [15-17]. The latter belongs to a family of proteins associated with the thin filament in muscle cells and microfilaments in non-muscle cells. Tropomyosin is not only a major crustacean allergen, it has also been demonstrated in a number of mollusk 
Table 2 Allergenic proteins characterized in shellfish and other invertebrates

\begin{tabular}{|c|c|c|c|c|}
\hline Group & Tropomyosin & Arginine kinase & Myosin light chain & Sarcoplasmic binding protein \\
\hline Crustacea & $\begin{array}{l}\text { Crab (Cha f 1) } \\
\text { North Sea shrimp (Cra c 1) } \\
\text { American lobster (Hom a 1) } \\
\text { Whiteleg shrimp (Lit v 1) } \\
\text { Shrimp (Pen a 1, Pen i 1) } \\
\text { Spiny lobster (Pen s 1) } \\
\text { Black tiger shrimp (Pen m 1) }\end{array}$ & $\begin{array}{l}\text { North Sea shrimp (Cra c 2) } \\
\text { Whiteleg shrimp (Lit v 2) } \\
\text { Black tiger shrimp (Pen m 2) }\end{array}$ & $\begin{array}{l}\text { Brine shrimp (Art fr 5) } \\
\text { North Sea shrimp (Cra c 5) } \\
\text { American lobster (Hom a 3) } \\
\text { Whiteleg shrimp (Lit v 3) } \\
\text { Black tiger shrimp (Pen m 3) }\end{array}$ & $\begin{array}{l}\text { North Sea shrimp (Cra c 4) } \\
\text { Whiteleg shrimp (Lit } \vee 4 \text { ) } \\
\text { Black tiger shrimp (Pen m 4) } \\
\text { Narrow-clawed crayfish (Pon | 4) }\end{array}$ \\
\hline Mollusca & $\begin{array}{l}\text { Pacific oyster (Cra g 1) } \\
\text { Abalone (Hal d 1) } \\
\text { Brown garden snail (Hel as } 1 \text { ) } \\
\text { Scallop (Mim n 1) } \\
\text { Tropical green mussel (Per } \vee 1 \text { ) } \\
\text { Squid (Tod p 1) }\end{array}$ & - & - & - \\
\hline $\begin{array}{l}\text { Other } \\
\text { invertebrates }\end{array}$ & $\begin{array}{l}\text { Anisakis simplex (Ani s 3) } \\
\text { Common roundworm (Asc | 3) } \\
\text { German cockroach (Bla g 7) } \\
\text { Blomia Tropicalis mite (Blo t 10) } \\
\text { Midge (Chi k 10) } \\
\text { House dust mite (Der f 10, Der p 10) } \\
\text { Storage mite (Lep d 10, Tyr p 10) } \\
\text { Silverfish (Lep s 1) } \\
\text { American cockroach (Per a 7) }\end{array}$ & $\begin{array}{l}\text { Silk moth (Bomb m 1) } \\
\text { House dust mite (Der p 20) } \\
\text { American cockroach (Per a 9) } \\
\text { Indianmeal moth (Plo i 1) }\end{array}$ & German cockroach (Bla g 8) & - \\
\hline
\end{tabular}

species [18]. In contrast to invertebrate tropomyosin, vertebrate tropomyosins are not allergenic. Dot blot and immunoblot analysis on subjects with a history of meat allergy to vertebrate meats did not show any IgE binding to tropomyosin of beef, pork, rabbit or chicken $[19,20]$. Similar studies demonstrated that shrimp allergic subjects' specific IgE did not cross react with any mammalian tropomyosins or their fragments [18,21].

Tropomyosin is heat stable [16], yet its allergenicity may change by certain processing methods. Boiling may result in the Maillard reaction (glycation) and formation of neoepitopes [22], as demonstrated that in some patients, boiled shrimp extract induced larger skin test responses than raw extract [23]. Also, shrimp extract treated with high intensity ultrasound for 180 minutes demonstrated decreased binding with sera from shrimp allergic patients [24].

In addition to tropomyosin, other allergens have been identified and characterized in shellfish. Arginine kinase a potential new class of invertebrate pan-allergens have been identified in Pacific white shrimp and Black tiger prawn as Lit v 2 and Pen $m 2$ respectively [25,26]. Arginine kinase has also been found in mollusks [27], along with other allergens such as myosin heavy chain, haemocyanin, and amylase [28]. However, the clinical significance of these allergens in mollusks is currently undefined.

Two other allergens identified in the Pacific white shrimp (Litopenaeus vannamei) are myosin light chain kinase [29] and sarcoplasmic calcium binding protein [30], identified as Lit v 3 and Lit v 4 respectively. Sarcoplasmic calcium binding protein seems to be an important allergen in the pediatric population, recombinant sarcoplasmic calcium binding protein was recognized by serum IgE from 20 of $52(38.4 \%)$ shrimp allergic subjects, with a higher frequency in children (17 out of $23 ; 74 \%$ ) than in adults (3 out of $29 ; 10 \%$ ) [30].

\section{Cross-reactivity within the shellfish family}

Subjects with shrimp hypersensitivity usually clinically react to other types of crustacea. Tropomyosin showed very high homologies of up to $98 \%$ among crustacean species, including crawfish, crab and lobster [17,31,32]. Crustacean allergic subjects also often react to species of the mollusk group. Leung et al [18] demonstrated in vitro that sera from nine crustacean allergic patients had IgE binding to antigens from all 10 mollusk species tested. However, in vitro cross-antigenicity does not necessarily indicate clinical cross allergenicity.

Furthermore, Jirapongsananuruk et al [33] demonstrated that shrimp allergy can be species-specific. Some studies reported clinical reactivity of $38 \%$ between shrimp and other crustacean members, $14 \%$ between crustacea and mollusks, and $49 \%$ between mollusk members $[3,18,34,35]$. It should be noted that these figures were derived primarily from self-reported clinical reactions.

\section{Cross-reactivity with other invertebrate antigens}

In patients with respiratory allergies, house dust mite (HDM) tropomyosin has been demonstrated to be a major allergen [36]. Tropomyosin from D. pteronyssinus (Der p 10) has homology of 75-80\% to shrimp and fruitfly 
and $65 \%$ to mollusks [37]. Tropomyosins from HDM and cockroach have high sequence identities to shellfish tropomyosin of around $80 \%[38,39]$. Such data indicate possible sensitization to tropomyosin by inhalation from a variety of non-crustacean sources [40], hence the emerging terminology "mite-crustaceans-mollusk syndrome".

In a study of 9 Orthodox Jews, who observe Kosher dietary laws that prohibit eating shellfish, the presence of IgE sensitization to shrimp was explored [41]. All 9 subjects had perennial respiratory allergies and positive HDM skin test, which was also positive to shrimp in all 9 and to cockroach in 2 of 7 tested.

High levels of serum IgE to tropomyosin is correlated with severity of shellfish allergy, however it may not be the only allergen responsible for shellfish sensitization in HDM sensitized individuals [42]. Sera from patients with shrimp allergy and HDM sensitivity but not reactive to tropomyosin were studied and found to cross react with a new $20-\mathrm{kDa}$ allergen present in both shrimp and HDM [43]. The authors postulated that this allergen could correspond to the sarcoplasmic calcium-binding protein and myosin light chain allergens. ArginineKinase found in decapod crustaceans and HDM (Der $\mathrm{p}$ 20) have also been proposed as a probable pan-allergen with $78 \%$ sequence homology with shrimp allergen Pen m 2 [44].

Some reports suggested that HDM injection immunotherapy may enhance sensitization or worsening allergy to shellfish [45-48]. However, a prospective study was conducted by Asero [49] on non shrimp-sensitized subjects receiving HDM injection immunotherapy for respiratory allergy and allowed to eat shellfish. After 3 years of HDM immunotherapy, participants showed no reactions to shrimp by skin testing or open oral challenge. Therefore, there is no strong evidence that shellfish allergy can develop through HDM immunotherapy.

It should be noted that crustacean and mollusk allergens do not cross-react with fish allergens and no reactivity between known allergens or homologous proteins have been demonstrated [50]. However, patients who are allergic to Anisakis simplex may react to parasitized fish or shellfish. Although tropomyosin might not be the major allergen in Anisakis allergy [51,52], possible clinical cross reactivity might occur in crustacean allergic subjects due to a high (74\%) amino acid sequence homology of crustacean and Anisakis tropomyosin [50,53-55].

\section{Clinical presentations of shellfish allergy}

Symptoms of shellfish allergy can range from mild urticaria to life threatening anaphylaxis. Most reactions are IgE-mediated with rapid onset and may be gastrointestinal, cutaneous, or respiratory. Symptoms may be limited to transient oral itching or burning sensation (oral allergy syndrome) within minutes of eating shellfish [50]. Recently, a case of food protein-induced enterocolitis syndrome to shellfish has been reported in a 6-yearold boy after ingestion of clam [56]. Food-dependent exercise-induced anaphylaxis has also been described to shellfish $[57,58]$. In certain subjects, anaphylaxis may result by a synergistic effect of nonsteroidal anti-inflammatory drugs with shellfish intake [59].

Shellfish protein is a potent allergen and can provoke symptoms by inhalation or skin contact [60]. Airborne allergens are particularly abundant in the vicinity of cooking shellfish by boiling, steaming, or frying. Occupational exposure, such as in snow crab processing plants, not only can cause symptoms in highly allergic subjects, but can also cause de novo sensitization [61]. Symptoms may be limited to the respiratory tract or affect other systems such as the skin or systemic anaphylaxis. The reported estimate of prevalence of occupational asthma in shellfish-processing workers is $2-36 \%$ [62].

Exposure by skin contact occurs more in occupational settings and the manifestations are commonly cutaneous in the form of urticaria or allergic contact dermatitis, although occasionally it can be systemic. The prevalence of occupational contact dermatitis to shellfish ranged from 3 to 11\% [62]. At least one case of contact urticaria to shrimp was reported to be caused by the protein in the shell and not to the meat itself [63].

\section{Diagnostic approach}

It is important at the outset to establish whether the adverse reaction is caused by shellfish allergy or toxicity. A detailed history is essential, with emphasis on the specific implicated type of seafood, the amount eaten, the type of symptoms, time of onset, and symptoms in other individuals who consumed the same meal. Management of food poisoning is mostly symptomatic.

In addition to the history and type of manifestation, allergic reactions are supported by documenting sensitization, i.e., positive skin test or elevated specific IgE level. Unless the patient had a life-threatening reaction, verification by a titrated oral challenge should be performed, preferably in a blind, placebo-controlled manner $[64,65]$. It is worth noting that skin testing with commercial extracts may give a false negative result whereas the prick-to-prick method can be more reliable, particularly by using the same implicated food. Carnes et al [23] demonstrated that using cooked instead of raw extracts for skin prick testing correlated well with food challenge.

If the medical history reveals concomitant factors, such as exercise, alcohol ingestion, or intake of nonsteroidal anti-inflammatory drugs, such factor(s) should be incorporated in the challenge test. 


\section{Management}

In general, management of any food allergy is basically strict avoidance based on proven clinical reactions and not mere sensitization. Because of cross-reactivity, avoidance of all crustacea is generally advised. Avoidance of mollusks is not necessary unless the patient is concomitantly allergic to it. Since cross-reactivity among crustacea is not complete, it is possible that allergy be limited to certain crustacea members. Patients should be alerted to possible inadvertent hidden exposure to the offending food, particularly in restaurants where cooking equipment or serving utensils may be used for different foods.

In addition to strict avoidance, patients who have had severe reactions should be advised to wear a Medic Alert identification and be trained in using epinephrine autoinjector. Because future reactions may be more severe $[66,67]$, some physicians tend to prescribe epinephrine autoinjectors to most food-allergic subjects.

Although there have been some recent investigational protocols for oral or sublingual immunotherapy to certain foods, to the best of our knowledge none has been done with shellfish. Perhaps some reports will be seen in the near future.

\section{Conclusion}

Shellfish is one of the major food allergens and its consumption is increasing worldwide. It is important to distinguish between shellfish allergy and toxicity as their presentations can mimic each other. Tropomyosin has been identified as the major allergen in the shellfish family and is responsible for the majority of the crossreactivity observed. However, newly discovered allergens and subtle differences in the structures of tropomyosin between different species of shellfish could account for the differences between cross-reactivity and true clinical reactions. Further research is needed to identify allergens with improved clinical sensitivity and species specificity which would aid in diagnosis. The primary management of shellfish allergy is avoidance. Patients who have immunodeficiency should only eat cooked shellfish due to the risk of severe infections from ingesting raw shellfish contaminated with infectious organisms.

\section{Authors' contributions \\ CKW collected and reviewed the literature and shared in preparing the manuscript. SLB shared in preparing the manuscript. All authors read and approved the final manuscript.}

\section{Competing interests}

The authors declare that they have no competing interests.
References

1. U.S. Seafood Consumption Declines Slightly in 2009. [http://www. noaanews.noaa.gov/stories2010/20100909_consumption.html].

2. Woods RK, Abramson M, Bailey M, Walters EH: International prevalences of reported food allergies and intolerances. Comparisons arising from the European Community Respiratory Health Survey (ECRHS) 1991-1994. Eur J Clin Nutr 2001, 55(4):298-304.

3. Sicherer SH, Munoz-Furlong A, Sampson HA: Prevalence of seafood allergy in the United States determined by a random telephone survey. J Allergy Clin Immunol 2004, 114(1):159-165.

4. Chiang WC, Kidon MI, Liew WK, Goh A, Tang JP, Chay OM: The changing face of food hypersensitivity in an Asian community. Clin Exp Allergy 2007, 37(7):1055-1061.

5. Shek LP, Cabrera-Morales EA, Soh SE, Gerez I, Ng PZ, Yi FC, Ma S, Lee BW: A population-based questionnaire survey on the prevalence of peanut, tree nut, and shellfish allergy in 2 Asian populations. J Allergy Clin Immunol 2010, 126(2):324-331, 331 e321-327..

6. Wood RA: The natural history of food allergy. Pediatrics 2003, 111(6 Pt 3):1631-1637.

7. Daul CB, Morgan JE, Lehrer SB: The natural history of shrimp hypersensitivity. J Allergy Clin Immunol 1990, 86(1):88-93.

8. Ayuso R, Sanchez-Garcia S, Lin J, Fu Z, Ibanez MD, Carrillo T, Blanco C, Goldis M, Bardina L, Sastre J, Sampson HA: Greater epitope recognition of shrimp allergens by children than by adults suggests that shrimp sensitization decreases with age. J Allergy Clin Immunol 2010, 125(6):1286-1293, e1283.

9. James KJ, Carey B, O'Halloran J, van Pelt FN, Skrabakova Z: Shellfish toxicity: human health implications of marine algal toxins. Epidemiol Infect 2010, 138(7):927-940.

10. Hungerford JM: Scombroid poisoning: a review. Toxicon 2010, 56(2):231-243

11. Chegini S, Metcalfe DD: Contemporary issues in food allergy: seafood toxin-induced disease in the differential diagnosis of allergic reactions. Allergy Asthma Proc 2005, 26(3):183-190.

12. Twiner MJ, Rehmann N, Hess P, Doucette GJ: Azaspiracid shellfish poisoning: a review on the chemistry, ecology, and toxicology with an emphasis on human health impacts. Mar Drugs 2008, 6(2):39-72

13. Structural Database of Allergenic Proteins. [http://fermi.utmb.edu/SDAP/]

14. Hoffman DR, Day ED Jr, Miller JS: The major heat stable allergen of shrimp. Ann Allergy 1981, 47(1):17-22.

15. Daul CB, Slattery M, Reese $G$, Lehrer SB: Identification of the major brown shrimp (Penaeus aztecus) allergen as the muscle protein tropomyosin. Int Arch Allergy Immunol 1994, 105(1):49-55.

16. Shanti KN, Martin BM, Nagpal S, Metcalfe DD, Rao PV: Identification of tropomyosin as the major shrimp allergen and characterization of its IgE-binding epitopes. J Immunol 1993, 151(10):5354-5363.

17. Leung PS, Chu KH, Chow WK, Ansari A, Bandea Cl, Kwan HS, Nagy SM, Gershwin ME: Cloning, expression, and primary structure of Metapenaeus ensis tropomyosin, the major heat-stable shrimp allergen. J Allergy Clin Immunol 1994, 94(5):882-890.

18. Leung PS, Chow WK, Duffey S, Kwan HS, Gershwin ME, Chu KH: IgE reactivity against a cross-reactive allergen in crustacea and mollusca: evidence for tropomyosin as the common allergen. J Allergy Clin Immunol 1996, 98(5 Pt 1):954-961.

19. Ayuso R, Lehrer SB, Tanaka L, Ibanez MD, Pascual C, Burks AW, Sussman GL, Goldberg B, Lopez M, Reese G: IgE antibody response to vertebrate meat proteins including tropomyosin. Ann Allergy Asthma Immunol 1999, 83(5):399-405

20. Restani P, Fiocchi A, Beretta B, Velona T, Giovannini M, Galli CL: Meat allergy: III-Proteins involved and cross-reactivity between different animal species. J Am Coll Nutr 1997, 16(4):383-389.

21. Reese G, Tracey D, Daul CB, Lehrer SB: IgE and monoclonal antibody reactivities to the major shrimp allergen Pen a 1 (tropomyosin) and vertebrate tropomyosins. Adv Exp Med Biol 1996, 409:225-230.

22. Nowak-Wegrzyn A, Fiocchi A: Rare, medium, or well done? The effect of heating and food matrix on food protein allergenicity. Curr Opin Allergy Clin Immunol 2009, 9(3):234-237.

23. Carnes J, Ferrer A, Huertas AJ, Andreu C, Larramendi CH, FernandezCaldas E: The use of raw or boiled crustacean extracts for the diagnosis of seafood allergic individuals. Ann Allergy Asthma Immunol 2007, 98(4):349-354 
24. Li ZX, Lin H, Cao LM, Jameel K: Effect of high intensity ultrasound on the allergenicity of shrimp. J Zhejiang Univ Sci B 2006, 7(4):251-256.

25. Garcia-Orozco KD, Aispuro-Hernandez E, Yepiz-Plascencia G, Calderon-de-laBarca AM, Sotelo-Mundo RR: Molecular characterization of arginine kinase, an allergen from the shrimp Litopenaeus vannamei. Int Arch Allergy Immunol 2007, 144(1):23-28.

26. Yu CJ, Lin YF, Chiang BL, Chow LP: Proteomics and immunologica analysis of a novel shrimp allergen, Pen m 2. J Immunol 2003, 170(1):445-453.

27. Uda K, Fujimoto N, Akiyama Y, Mizuta K, Tanaka K, Ellington WR, Suzuki T: Evolution of the arginine kinase gene family. Comp Biochem Physiol Part D Genomics Proteomics 2006, 1(2):209-218.

28. Taylor SL: Molluscan shellfish allergy. Adv Food Nutr Res 2008, 54:139-177

29. Ayuso R, Grishina G, Bardina L, Carrillo T, Blanco C, Ibanez MD, Sampson HA, Beyer $\mathrm{K}$ : Myosin light chain is a novel shrimp allergen, Lit v 3. J Allergy Clin Immunol 2008, 122(4):795-802.

30. Ayuso R, Grishina G, Ibanez MD, Blanco C, Carrillo T, Bencharitiwong R, Sanchez S, Nowak-Wegrzyn A, Sampson HA: Sarcoplasmic calcium-binding protein is an EF-hand-type protein identified as a new shrimp allergen. $J$ Allergy Clin Immunol 2009, 124(1):114-120.

31. Leung PS, Chen YC, Gershwin ME, Wong SH, Kwan HS, Chu KH: Identification and molecular characterization of Charybdis feriatus tropomyosin, the major crab allergen. J Allergy Clin Immunol 1998, 102(5):847-852.

32. Leung PS, Chen YC, Mykles DL, Chow WK, Li CP, Chu KH: Molecular identification of the lobster muscle protein tropomyosin as a seafood allergen. Mol Mar Biol Biotechnol 1998, 7(1):12-20.

33. Jirapongsananuruk $O$, Sripramong $C$, Pacharn $P$, Udompunturak $S$, Chinratanapisit S, Piboonpocanun S, Visitsunthorn N, Vichyanond P: Specific allergy to Penaeus monodon (seawater shrimp) or Macrobrachium rosenbergii (freshwater shrimp) in shrimp-allergic children. Clin Exp Allergy 2008, 38(6):1038-1047.

34. Lehrer SB, McCants ML: Reactivity of IgE antibodies with crustacea and oyster allergens: evidence for common antigenic structures. J Allergy Clin Immunol 1987, 80(2):133-139

35. Waring NP, Daul CB, deShazo RD, McCants ML, Lehrer SB: Hypersensitivity reactions to ingested crustacea: clinical evaluation and diagnostic studies in shrimp-sensitive individuals. J Allergy Clin Immunol 1985, 76(3):440-445

36. Aki T, Kodama T, Fujikawa A, Miura K, Shigeta $S$, Wada $T$, Jyo T, Murooka $Y$ Oka S, Ono K: Immunochemical characterization of recombinant and native tropomyosins as a new allergen from the house dust mite, Dermatophagoides farinae. J Allergy Clin Immunol 1995, 96(1):74-83.

37. Reese G, Ayuso R, Lehrer SB: Tropomyosin: an invertebrate pan-allergen Int Arch Allergy Immunol 1999, 119(4):247-258.

38. Ayuso R, Lehrer SB, Reese G: Identification of continuous, allergenic regions of the major shrimp allergen Pen a 1 (tropomyosin). Int Arch Allergy Immunol 2002, 127(1):27-37.

39. Santos AB, Chapman MD, Aalberse RC, Vailes LD, Ferriani VP, Oliver $C$ Rizzo MC, Naspitz CK, Arruda LK: Cockroach allergens and asthma in Brazil: identification of tropomyosin as a major allergen with potential cross-reactivity with mite and shrimp allergens. J Allergy Clin Immunol 1999, 104(2 Pt 1):329-337.

40. Witteman AM, Akkerdaas JH, van Leeuwen J, van der Zee JS, Aalberse RC: Identification of a cross-reactive allergen (presumably tropomyosin) in shrimp, mite and insects. Int Arch Allergy Immunol 1994, 105(1):56-61.

41. Fernandes J, Reshef A, Patton L, Ayuso R, Reese G, Lehrer SB: Immunoglobulin $E$ antibody reactivity to the major shrimp allergen, tropomyosin, in unexposed Orthodox Jews. Clin Exp Allergy 2003, 33(7):956-961

42. Boquete $\mathrm{M}$, Iraola V, Morales M, Pinto H, Francisco C, Carballas C, Carnes J: Seafood hypersensitivity in mite sensitized individuals: is tropomyosin the only responsible allergen? Ann Allergy Asthma Immunol 2011, 106(3):223-229.

43. Villalta D, Tonutti E, Visentini D, Bizzaro N, Roncarolo D, Amato S, Mistrello G: Detection of a novel $20 \mathrm{kDa}$ shrimp allergen showing crossreactivity to house dust mites. Eur Ann Allergy Clin Immunol 2010, 42(1):20-24

44. Binder M, Mahler V, Hayek B, Sperr WR, Scholler M, Prozell S, Wiedermann G, Valent P, Valenta R, Duchene M: Molecular and immunological characterization of arginine kinase from the Indianmeal moth, Plodia interpunctella, a novel cross-reactive invertebrate panallergen. J Immunol 2001, 167(9):5470-5477.

45. Pajno GB, La Grutta S, Barberio G, Canonica GW, Passalacqua G: Harmful effect of immunotherapy in children with combined snail and mite allergy. J Allergy Clin Immunol 2002, 109(4):627-629.

46. van Ree R, Antonicelli L, Akkerdaas JH, Pajno GB, Barberio G, Corbetta L, Ferro G, Zambito M, Garritani MS, Aalberse RC, Bonifazi F: Asthma after consumption of snails in house-dust-mite-allergic patients: a case of $\lg E$ cross-reactivity. Allergy 1996, 51(6):387-393.

47. van Ree R, Antonicelli L, Akkerdaas JH, Garritani MS, Aalberse RC, Bonifazi F: Possible induction of food allergy during mite immunotherapy. Allergy 1996, 51(2):108-113.

48. Peroni DG, Piacentini GL, Bodini A, Boner AL: Snail anaphylaxis during house dust mite immunotherapy. Pediatr Allergy Immunol 2000, 11(4):260-261

49. Asero R: Lack of de novo sensitization to tropomyosin in a group of mite-allergic patients treated by house dust mite-specific immunotherapy. Int Arch Allergy Immunol 2005, 137(1):62-65.

50. Lopata AL, O'Hehir RE, Lehrer SB: Shellfish allergy. Clin Exp Allergy 2010, 40(6):850-858

51. Asturias JA, Eraso E, Moneo I, Martinez A: Is tropomyosin an allergen in Anisakis? Allergy 2000, 55(9):898-899.

52. Moneo I, Caballero ML, Gomez F, Ortega E, Alonso MJ: Isolation and characterization of a major allergen from the fish parasite Anisakis simplex. J Allergy Clin Immunol 2000, 106(1 Pt 1):177-182.

53. Guarneri F, Guarneri C, Benvenga S: Cross-reactivity of Anisakis simplex: possible role of Ani s 2 and Ani s 3. Int J Dermatol 2007, 46(2):146-150.

54. Johansson E, Aponno M, Lundberg M, van Hage-Hamsten M: Allergenic cross-reactivity between the nematode Anisakis simplex and the dust mites Acarus siro, Lepidoglyphus destructor, Tyrophagus putrescentiae, and Dermatophagoides pteronyssinus. Allergy 2001, 56(7):660-666.

55. Arlian LG, Morgan MS, Quirce S, Maranon F, Fernandez-Caldas E: Characterization of allergens of Anisakis simplex. Allergy 2003 58(12):1299-1303.

56. Hayashi D, Aoki T, Shibata R, Ichikawa K: [Case of food protein-induced enterocolitis syndrome caused by short-neck clam ingestion]. Arerugi 2010, 59(12):1628-1633

57. Maulitz RM, Pratt DS, Schock, et al: Exercise-induced anaphylactic reaction to shellfish. J Allergy Clin Immunol 1979, 63(6):433-434

58. Tokunaga $\mathrm{H}$, Kokubu F, Okamoto M, Miyamoto M, Hanyuuda M, Adachi M: [A case of food-dependent exercise-induced anaphylaxis induced by shrimp]. Arerugi 1995, 44(11):1297-1304

59. Vidal C, Bartolome B, Gonzalez-Quintela A, Rodriguez V, Armisen M: Prawns, barnacles, and nonsteroidal anti-inflammatory drugs: effect modifiers or diagnostic confounders [corrected]. J Investig Allergol Clin Immunol 2007, 17(2):113-118

60. Ramirez DA Jr, Bahna SL: Food hypersensitivity by inhalation. Clin Mol Allergy 2009, 7:4

61. Weytjens K, Cartier A, Malo JL, Chretien P, Essiembre F, Lehrer S, Swanson M: Aerosolized snow-crab allergens in a processing facility. Allergy 1999, 54(8):892-893.

62. Jeebhay MF, Robins TG, Lehrer SB, Lopata AL: Occupational seafood allergy: a review. Occup Environ Med 2001, 58(9):553-562

63. Nagano T, Kanao K, Sugai T: Allergic contact urticaria caused by raw prawns and shrimps: three cases. J Allergy Clin Immunol 1984, 74(4 Pt 1):489-493

64. Bahna SL: Food challenge procedure: optimal choices for clinical practice. Allergy Asthma Proc 2007, 28(6):640-646.

65. Nowak-Wegrzyn A, Assa'ad AH, Bahna SL, Bock SA, Sicherer SH, Teuber SS: Work Group report: oral food challenge testing. J Allergy Clin Immunol 2009, $123(6$ Suppl):S365-383.

66. Sicherer SH, Furlong TJ, Munoz-Furlong A, Burks AW, Sampson HA: A voluntary registry for peanut and tree nut allergy: characteristics of the first 5149 registrants. J Allergy Clin Immunol 2001, 108(1):128-132.

67. Atkins D, Bock SA: Fatal anaphylaxis to foods: epidemiology, recognition, and prevention. Curr Allergy Asthma Rep 2009, 9(3):179-185.

doi:10.1186/2045-7022-1-3

Cite this article as: Woo and Bahna: Not all shellfish "allergy" is allergy!. Clinical and Translational Allergy 2011 1:3. 